DOI: $\square$ https://doi.org/10.15407/techned2020.06.021

\title{
OPTIMIZATION OF ACTIVE CORRECTOR ELEMENTS OF CURRENT FORM IN COMPOSITION OF HYBRID FILTER BY ALGORITHM OF SWITCHING OF INVERTER TRANSISTORS
}

$\quad$ Journal
Publisher
ISSN
Issue
Pages

Tekhnichna elektrodynamika Institute of Electrodynamics National Academy of Science of Ukraine 1607-7970 (print), 2218-1903 (online)

No 6, 2020 (November/December)

$21-24$

\section{Authors}

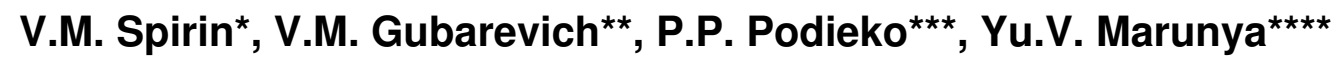
Institute of Electrodynamics of National Academy of Sciences of Ukraine, pr. Peremohy, 56, Kyiv, 03057, Ukraine, e-mail: sspirin@ied.org.ua

* ORCID ID : https://orcid.org/0000-0002-8065-1051

** ORCID ID : https://orcid.org/0000-0003-2416-9858

*** ORCID ID : https://orcid.org/0000-0001-9201-102X

**** ORCID ID : https://orcid.org/0000-0003-0071-1702

\section{Abstract}

The algorithm for switching transistors of the inverter of the active corrector of current form is defined, which allow to reduce the maximum frequency of their switching or the inductance of the reactor of the active corrector of current form in a hybrid filter, which consists of a cascade connection of a parallel active filter and a series-parallel passive LMC-filter. References 10, figures 5 .

Key words: active corrector of current form, hybrid filter, inverter. 
Accepted: 21.05 .2020

Published: 21.10 .2020

\section{References}

1. Muhammad H. Rashid. Power Electronics Handbook. N.Y.: Academic Press, 2001. 876 p.

2. Electromagneticcompatibility. Part 3-2: Limits. Limits for harmonic currents produced by equipment connected to public low-voltage systems with input currents $>16 \mathrm{~A}$ and $\leq 75 \mathrm{~A}$ per phase. IEC 61000.3.12:2011.

3. Zharkin A.F., Palachev S.O., Novsky V.A. Regulatory regulation of voltage quality in electric networks with sources of dispersed generation. Kyiv: Nash format, 2018. 160 p. (Ukr)

4. Komarov M.S., Golovko O.O., Bulatov A.Yu., Podeyko P.P. Energy-saving technologies in computer classrooms and educational labs in educational institutions. Visnyk KNUTD. 2013. No 6. Pp. 278-286. (Ukr)

5. Kulinich Yu.A., Dukhovnikov V.K. Active reactive power compensator as a means of improving the quality of energy consumed. Nauka i Transport. 2010. No 3 (28). Pp. 38-40.

(Rus)

6. Kucherenko D.V., Safronov P.S. Parallel active filter of higher harmonics of current. Visnyk NTU KhPI

. Series: Novi rishennia v suchasnykh tekhnologiiakh. 2013. No 18 (991). Pp.41-46. (Rus)

7. Statsenko O.V. Analysis of parallel active current corrector operation with relay control. Visn yk KNUTD

. 2015. No 5 (90). Pp. 113-117. (Ukr)

8. Bose B. K.. Modern Power Electronics and AC Drives. Prentice Hall PTR, 2002. 711 p.

9. Komarov M.S., Spirin V.M., Gubarevich V.M., Podeyko P.P., Marunya Yu.V. Optimization of electromagnetic units-reactors with different core materials for active correctors of current form. Electrical Engineering and Electromechanics

. 2016. No 4 (2). Special edition. Vol. 2. Pp. 71-74. (Ukr)

10. Volkov I.V., Styazhkin V.P., Podeyko P.P. Topology of filter compensating devices for improving the input current range of power sources in electrothermal installations for the production of basalt superfine. Tekhnichna elektrodynamika. 2018. No 6. Pp. 85-88. (Ukr) DOI: https://doi.org/10.15.407/techned2018.06.085 


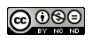

This work is licensed under a Creative Commons Attribution-NonCommercial-NoDerivatives 4.0 International License 